\title{
Klaim Republik Rakyat China atas Zona Ekonomi Ekslusif Indonesia
}

\section{Efie Baadilla}

Fakultas Hukum Universitas Pattimura, Ambon, Indonesia E-mail: efiebaadilla@gmail.com

Dikirim: 09/06/2020

\begin{tabular}{l}
\hline Info Artikel \\
Keywords: \\
Claims; Zone \\
Economic Exclusive; \\
South China Sea. \\
\\
Kata Kunci: \\
Klaim; ZEE; Laut \\
China Selatan.
\end{tabular}

Direvisi: $18 / 08 / 2020$

Dipublikasi: 08/09/2020

Abstract

The South China Sea is a strategic marine area and contains both living and non-living natural resources. The purpose of this paper is to analyze China's claim to Indonesia's ZEE in the South China Sea, which is known to Indonesia as the North Natuna Sea. China's claim to the Nine dash line in the South China Sea has had an impact on Indonesia and several countries. The research method uses normative research with a statute approach and a conceptual approach. The results of his study show that the recent conflict between Indonesia and China in the South China Sea has brought about a new conflict between the two countries even though Indonesia has so far not considered a problem. In fact, the application of the nine dash line as Traditional fishing grounds was not known in UNCLOS 1982, but the concept known was Traditional fishing rights. Indonesia has sovereignty and sovereign rights over North Natuna waters based on UNCLOS, for this reason, Indonesia needs to continue to carry out exploitation and exploration activities, supervision and legal action to guarantee the sovereign rights of the State. 
DOI:

10.47268/sasi.v26i3.395 berdasarkan UNCLOS, untuk itu Indonesia perlu tetap melakukan aktifitas eksploitasi dan eksplorasi, pengawasan dan tindakan hukum untuk menjamin hak-hak berdaulat Negara.

\section{A. PENDAHULUAN}

Laut dengan keanekaragaman sumber daya alam ini diolah dan dimanfaatkan untuk kebutuhan manusia, akan memberikan pelbagai peluang guna memecahkan berbagai persoalan baik secara nasional maupun internasional dipelbagai kawasan dunia. ${ }^{1}$ Konflik Laut Cina Selatan (LCS) yang hingga saat ini belum terselesaikan, telah berdampak terhadap Indonesia sebagai negara yang memiliki wilayah yurisdiksi nasional pada Zona Ekonomi Eksklusif Indonesia (ZEEI) Laut Natuna Utara. ${ }^{2}$

Keamanan maritim Indonesia tidak dirasakan secara langsung oleh Indonesia karena aktivitas militer asing di ZEE Indonesia tidak pernah secara langsung bertentangan dengan kepentingan Indonesia di ZEE Indonesia, namun secara berkepanjangan dapat memicu konflik antara Indonesia dan negara asing yang melakukan aktivitas militer di ZEE Indonesia. ${ }^{3}$ Laut China Selatan adalah suatu wilayah laut yang merupakan jalur laut yang sangat strategis dan kaya akan potensi sumber daya alam hayati dan non hayati. Laut ini dikelilingi oleh negara Republik Rakyat Tiongkok (selanjutnya disebut China),Taiwan, Vietnam, Kamboja, Thailand, Malaysia, Singapura, Indonesia, Brunai Darusalam dan Filipina.

Kawasan Laut China Selatan menjadi pusat perhatian dan konflik akhir-akhir ini disebabkan klaim sepihak Nine dash line atau Sembilan garis putus yang berada di tengah laut di Laut China Selatan dan menjorok masuk ke ZEE Natuna Utara. China tidak mengakui klaim Indonesia atas dasar kedaulatan Pulau Nansha yang berada dalam Sembilan garis putus dan pulau tersebut memiliki perairan sejenis ZEE. Perairan sejenis ZEE disebut China sebagai Traditional Fishing Grounds. ${ }^{4}$ Indonesia merupakan salah satu Negara yang terancam dirugikan karena aksi China menggambarkan Sembilan titik wilayah baru kepulauan Natuna. ${ }^{5}$

Pada bulan Mei 2015, Kementerian Luar Negeri China memprotes Pemerintah Indonesia karena melakukan penangkapan terhadap delapan nelayan mereka yang masuk perairan Natuna dan ancaman tindakan penembakan terhadap kapal nelayan China oleh TNI Angkatan Laut di perairan Kepulauan Natuna. Menurut China ini merupakan wilayah tradisional penangkapan ikan nelayan China. Pihak China dalam menentukan batas lautnya bersifat unilateral yaitu dengan Nine dash line yang tidak diakui oleh Negara-negara yang berbatasan dengan China di Laut Cina Selatan. Disisi lain delegasi China tidak pernah mengklaim dan memberikan dasar teori yang jelas tentang Nine dash line dalam forum Konprensi Hukum Laut yang dimulai dari tahun 1973 dan berakhir pada tahun 1982. Konvensi ini telah dinyatakan berlaku setelah diratifikasi oleh 60 negara. Saat ini sudah 158 negara,termasuk Uni Eropah, China, Indonesia telah meratifikasi United Nation Convention

1 Rehatta, V. J. B. (2014), "Penyelesaian Sengketa Perikanan di Laut Lepas Menurut Hukum Internasional", SASI, 20 (1): 62-68, h. 64.

2 Santoso, T. I., (2020), “Aksi Agresivitas Cina Pada Zona Ekonomi Eksklusif Indonesia Laut Natuna Utara: Perspektif Tugas Pokok TNI”. Jurnal Kajian Lemhannas RI, Edisi 41 (Maret): 35-46, h. 36.

${ }^{3}$ Gumilang, E; Utomo, H; Buntoro, K. (2018). "Dampak Aktivitas Militer Asing Di Zona Ekonomi Eksklusif Indonesia Terhadap Keamanan Maritim Indonesia”, Jurnal Keamanan Maritim, 4(3): 21-42, h. 21.

4 Juwana, H. "Dialog tvOne: Kapal Cina Masuk Laut Natuna", Tanggal 5 Januari 2020

5 Tampi, B. (2017), "Konflik Kepulauan Natuna Antara Indonesia dengan China (Suatu Kajian Yuridis)", Jurnal Hukum Unsrat, 23 (10): 1-16, h. 1. 
Sejumlah kejadian yang terjadi di Laut China Selatan khususnya ZEE Indonesia pada 10 Maret 2019 di mana kapal Coast Guard China membenturkan kapal berbendera China yang sedang ditarik oleh kapal Kementerian Kelautan dan Perikanan Indonesia karena diduga melakukan penangkapan ikan yang tidak sah (illegal fishing ) di ZEE Indonesia. Tindakan yang dilakukan Coast Guard China yang tidak menghormati tindakan penegakkan hukum yang dilakukan oleh otoritas Indonesia di wilayah hak berdaulat (sovereign right) Indonesia. Tindakan tersebut mengindikasikan penegasan China atas klaim Nine dash line terhadap Indonesia dan Negara-negara lain diseputar Laut China Selatan. Nine dash line ialah garis berbentuk "U" berawal dari Selatan Dataran China dan berujung dikawasan Natuna, melintasi lautan diantara Vietnam, Philipina, Brunai Darusalam dan Malaysia. ${ }^{7}$ Klaim yang dilakukan China ini, maka tidak ada satu Negara pun yang bisa mengaku kedaulatan di kawasan Laut Cina Selatan. Pemerintah China telah lama mengklaim wilayah Laut Cina Selatan pertama kali dengan "eleven dash line" pada tahun 1947 yang muncul di peta Republik Rakyat Tiongkok dan mulai dipublikasi sejak Februari 1949.

Sejak terbit peta China pada tahun 1943, China menganggap batas Selatan lautnya adalah sampai Kepulauan Prata dan Paracel dan menjorok ke Laut Natuna. Klaim China Ini didasarkan pada alasan historis yang secara hukum internasional, utamanya UNCLOS tidak memiliki dasar hukum. ${ }^{8}$ Pemerintah Tiongkok pada tanggal 7 Mei 2009 secara resmi mendaftarkan klaim "Nine dash line" ke Peserikatan Bangsa Bangsa. Indonesia adalah Negara kepulauan yang telah meperjuangkan prinsip-prinsip Negara kepulauan dalam Konperensi Hukum Laut Pertama, Kedua dan yang ketiga berhasil memperoleh legitimasi hukum dengan masuknya pasal-pasal Negara Kepulauan dalam UNCLOS 1982 dan menjadi dasar Pemerintah Indonesia menetapkan wilayah laut Negara Republik Indonesia mulai dari laut territorial, ZEE dan Landas Kontinen. Bagaimana Konvensi Hukum Laut 1982 mengatur hal tersebut dalam kaitan dengan klaim China di laut China Selatan.

\section{B. PEMBAHASAN}

\section{Pemetaan Wilayah Laut Berdasarkan UNCLOS 1982}

Kewajiban untuk membuat pegaturan mengenai peraturan perbatasan sementara antara kedua negara diatur dalam Pasal 74 ayat (3) dan Pasal 83 ayat (3) UNCLOS yang mengatakan sambil menunggu suatu persetujuan delimitasi batas maritim, Negara-negara yang bersangkutan, dengan semangat saling pengertian dan kerjasama, harus melakukan upaya untuk mengadakan pengaturan sementara yang bersifat praktis dan, selama masa peralihan ini, tidak membahayakan atau menghalangi dicapainya suatu persetujuan akhir. ${ }^{9}$ Wilayah laut adalah laut berserta tanah yang ada di bawahnya. Tanah di bawah laut terdiri dari dasar laut dan tanah di bawah dasar laut. Wilayah laut terbagi atas wilayah yang dikuasai oleh satu (negara pantai) dengan laut yang tidak dikuasai oleh Negara. ${ }^{10}$

Pasal 55 UNCLOS "Zona Ekonomi Eksklusif ialah suatu daerah di luar dan berdampingan dengan laut territorial, yang tunduk pada rezim hukum khusus yang

6 Subagyo, P. J. (2005). Hukum Laut Indonesia, Jakarta: Rineka Cipta.

7 Haiton, B. (2009), "The Modern Origins of Chinas South China Sea Claims: Maps, Misunderstandings, and the Maritime Goebody", Sage Journals

8 Juwana, H, "Press Release", 28 Januari 2020

9 Monteiro, S. (2020), "Yurisdiksi Negara Pantai di Wilayah Delimitasi Maritim Zona Ekonomi Eksklusif yang Belum Ditetapkan Berdasarkan Ketentuan Hukum Laut Internasional (Study Di Timor LesteIndonesia)", Jurnal Komunikasi Hukum, 6 (1): 303-334, h. 303.

10 Sefriani, (2017). Hukum Internasional: Suatu Pengantar, Jakarta: Rajawali Pers, h. 180. 
ditetapkan berdasarkan mana hak-hak dan yurisdiksi negara pantai dan hak-hak serta kebebasan-kebebasan negara lain, diatur oleh ketentuan-ketentuan yang relevan dalam konvensi ini".Luas ZEE tidak boleh melebihi 200 mil laut dari garis pangkal dari mana lebar laut territorial diukur. ( Pasal 57 UNCLOS)

\section{Hak-hak yusidiksi dan kewajiban Negara pantai dl ZEE ialah : ${ }^{11}$}

a) Hak berdaulat (sovereign rights) untuk melakukan eksplorasi dan eksploitasi, konservasi dan pengelolaan Sumber Daya Alam.

b) Pendirian dan penggunaan pulau-pulau buatan, riset ilmiah dan perlindungan lingkungan laut.

c) Kebebasan pelayaran

Dari ketentuan pasal-pasal yang mengatur tentang ZZE dalam UNCLOS 1982 bahwa Negara pantai mempunyai hak berdaulat khusus untuk sumber-sumber daya alam dan laut di atasnya adalah laut bebas. Laut bebas bukan berarti dapat dieksploitasi Negara lain seperti eksploitasi perikanan tanpa ijin (illegal fishing) yang sering dilakukan oleh nelayan-nelayan asing terutama nelayan China, Thailand, Malaysia di ZEE Indonesia.

Pembahasan ZEE atau klaim Negara terhadap ZEE tidak dapat dipisahkan dari laut territorial, dimana cara penentuan garis pangkal ZEE 200 mil diukur. Laut territorial adalah laut yang terletak pada sisi luar dari garis pangkal kepulauan dan tidak boleh melebihi 12 mil laut (Pasal 3).Garis pangkal biasa untuk mengukur lebar laut teritorial adalah pada garis air pasang surut terendah (Pasal 5). Apabila garis pantai sangat menjorok ke dalam atau apabila terdapat jajaran pulau-pulau di sepanjang pantai, suatu garis pangkal lurus dapat ditarik dari titik-titk terluar pada pantai atau pulau-pulau terluar tersebut (Pasal 7). Sedangkan suatu Negara kepulauan seperti Indonesia adalah Negara yang seluruhnya terdiri dari satu atau lebih kepulauan. Negara dapat menarik garis pangkal lurus yang menghubungkan titik-titik terluar pada pulau-pulau terluar dari gugusan kepulauan tersebut, dengan pulau utama termasuk ke dalam garis garis-garis pangkal tersebut dengan perbandingan antara perairan dan daratan tidak melebihi $9: 1$ (Pasal 47). ${ }^{12}$

Konfigurasi geografis Republik China sebagai negara continental, seharusnya menarik titik-titik terluar dari daratan China mempergunakan garis pangkal biasa dan garis pangkal lurus pasal 5 UNCLOS. Indonesia sebagai Negara kepulauan sesuai ketentuan pasal 48 mempergunakan garis pangkal kepulauan untuk menarik garis pangkal lurus yang menghubungkan titik-titik terluar pada pulau-pulau terluar dari gugusan kepulauan Indonesia. Pasal 46 UNCLOS mengartikan suatu kepulauan sebagai kelompok pulau-pulau dan perairan yang menghubungkannya dan saling berkaitan dengan eratnya, sehingga membentuk kesatuan geografis, ekonomi dan politik atau secara historis telah dianggap demikian.

Perbedaan pemikiran Pemerintah Republik Rakyat China sebagai Negara continental dengan Negara-negara tetangga yang sebagian besar adalah negara kepulauan dan tunduk pada ketentuan Bab IV tentang Negara kepulauan. Perbedaan kedudukan dan klasifikasi Negara dalam Konvensi 1982 inilah yang berarti terdapat perbedaan hak kedua Negara dalam menggunakan garis pangkal untuk menarik dan menentukan wilayah laut territorial 12 mil dan ZEE 200 mil serta Landas Kontinen. Sebagai Negara berpantai (coastal state), maka untuk menentukan delimitasi batas laut menggunakan garis pangkal normal (normal baseline), atau jika garis pangkal normal tidak dapat digunakan karena kondisi lain yang

11 Koers, A. W, (1994). Konvensi Perserikatan Bangsas-Bangsa tentang Hukum Laut, Yokyakarta: Gajah Mada University Press, h. 8

12 Koers, A. W, Ibid. h. 6. 
dibenarkan dalam UNCLOS. Sebagai Negara Kepulauan Indonesia berhak menarik titiktitik terluar pulau-pulau terluar untuk nenentukan wilayah 12 mil laut territorial dan 200 mil ZEE. Kualifikasi Indonesia sebagai negara kepulauan (archipelagic state) maka cara penarikan garis pangkal ZEE Indonesia ditarik dari titik-titik terluar pulau terluar kepulauan Natuna yaitu Natuna Utara maka akan terjadi bersinggungan dengan klaim China dengan penggunaan sembilan garis putus yang menjorok masuk ke Natuna Utara. Sebagai negara continental, Pemerintah China tidak mempunyai dasar hokum klaim sembilan garis putus tersebut. Klaim China didasarkan atas kedaulatan teritorial Pulau Nansha di Laut China Selatan yang dianggap mempunyai perairan sejenis ZEE. Perairan sejenis ZEE ini disebut China sebagai Traditional fishing grounds. Ketentuan dalam UNCLOS, sebagaimana diatur dalam Pasal 51 mengenal Traditional fishing rights bukan Traditional fishing grounds yang diklaim China.

Klaim China di Laut China Selatan diprotes oleh Filipina dan pada Tahun 2013 mengajukan gugatan melalui Parmanen Court Arbitrasion tentang klaim wilayah Traditional fishing ground dengan cara pengukuran menggunakan Sembilan garis putus-putus di luar kedaulatan Negaranya. Menurut Pemerintah Filipina tidak terdapat landasan Hukum Internasional atas klaim tersebut.

Pada tahun 2016 Mahkamah Arbritasi Internasional memeriksa dan mumutuskan tentang keberatan yang diajukan oleh Filipina secara umum menetapkan putusannya tentang dua hal utama yaitu pertama, Mahkamah menyatakan tidak ada bukti sejarah bahwa China menguasai dan mengendalikan sumber daya alam secara eksklusif di Laut Cina Selatan, sehingga menyatakan tidak ada dasar hukum atas klaim Pemerintah China terhadap nine dash line di laut China Selatan. Kedua, Mahkamah menyatakan bahwa objek geografis (pulau, karang, low-tide elevation) yang ada pada kawasan Laut Cina Selatan tidak berhak atas ZEE 200 mil yang diukur 12 mil dari pulau, karang dilepas pantai China.

Apabila kita mencermati cara penyelesaian masalah di laut China Selatan, maka Negara-negara peserta Konvensi diwajibkan menyelesaikan sengketa yang menyangkut penafsiran dan penerapan Konvensi melalui cara-cara damai sesuai Pasal 2, paragraph 3 Piagam PBB dan Pasal 279 UNCLOS. Prinsip dasarnya bahwa Negara-negara bebas memilih cara-cara penyelesaian sendiri pasal 280 dan bahwa apabila para pihak yang bersengketa telah memilih cara penyelesaian, maka prosedur yang diatur Konvensi diterapkan hanya jika cara penyelesaian yang mereka pilih itu tidak berhasil dan para pihak tidak menutup kemungkinan adanya prosedur lanjutan, (Pasal 281). Langkah awal dalam penyelesaian suatu sengketa adalah melalui perjanjian, karena pasal 283 menekankan perlunya bertukar pandangan mengenai cara-cara bagaimna sengketa itu diselesaikan. Suatu Negara yang bersengketa mengenai penafsiran dan penerapan Konvensi' bisa juga menyerahkan kepada konsiliasi sesuai dengan prosedur yang terdapat dalam Annex Konvenasi pasal 284. Prosedur wajib untuk mencapai suatu keputusan mengikat maka, negara-negara dapat memilih satu atau lebih cara penyelesaian sengketa : (a) Mahkamah Internasional Hukum Laut (b) Mahkamah Internasional (c) Mahkamah Arbitrase (d) Untuk sengketa tertentu Mahkamah Arbitrase Khusus (Pasal 287(1). Apabila suatu Negara tidak memilih cara penyelesain maka Negara itu dianggap telah menerima Mahkamah Arbitrase sebagaimana termaksud dalam point (c) di atas. Keputusan Pengadilan atau Mahkamah, sebagaimana diatur pasal 287 bersifat final dan mengikat. ${ }^{13}$

13 Koers, A. W, Ibid. hl. 71. 


\section{Ilegal Fishing di Laut China Selatan}

Pokok masalah Laut China Selatan yang paling aktual muncul kembali antara Indonesia dan China karena banyaknya kapal-kapal ikan China yang dilindungi Coast Guard menangkap ikan di 200 mil ZEE Indonesia.Sesuai ketentuan Pasal 57 UNCLOS suatu Negara berpantai berhak terhadap potensi sumber daya alam hayati di ZEE.Sebagai Negara berpantai China memiliki perbedaan konsep yang telah disepakati Negara-negara dalam perundingan pada Konperensi Hukum Laut ke 3 yang dimulai pada tahun 1973 dan ditandatangani oleh negara-negara dunia peserta konperensi pada tahun 1982 sehingga disebut Konvensi Hukum Laut 1982 atau UNCLOS 1982.

Di dalam pasal-pasal yang termuat dalam UNCLOS1982 tidak dikenal konsep yang selalu dikemukakan China yaitu pertama Eleven dash nine (Tahun 1947) kemudian dirubah menjadi Nine dash line dan kedua Traditional fishing ground yang diklaim China di wilayah perairan di Laut China Selatan. ${ }^{14}$

Jika tanpa perjanjian bilateral, maka sesuai dengan UNCLOS 1982 Historical Traditonal Fishing Ground dan dikategorikan sebagai satu diantara IUU Fishing dan pelanggaran atas yurisdiksi dan integritas teritorial Indonesia, dimana otoritas hukum Indonesia berhak menindak setiap nelayan yang mengklaim memiliki hak traditional fishing right ditindak sesuai mekanisme hukum Indonesia. ${ }^{15}$

Di dalam ketentuan pasal - pasal yang telah disepakati bersama apabila secara historis terdapat kebiasaan nelayan-nelayan menangkap ikan secara tradisonal di laut antara dua (2) Negara maka dapat disepakati wilayah tersebut adalah wilayah traditional fishing right melalui perjanjian yang diatur dalam Pasal 51 ayat (1) UNCLOS, ini meliputi hak-hak Negara bertetangga yang berdampingan langsung dengan Negara kepulauan untuk melakukan penangkapan secara tradisional (traditional fishing rights) dan kegiatan legal lainnya pada kawasan tertentu di dalam perairan kepulauan.

Saat berlangsungnya Konperensi Hukum Laut ke 3 sejak tahun 1973 tidak ada konsep yang diusulkan China sebagai Traditional fishing ground dan cara penarikan garis maritim yang disebut Nine dash line. Pemerintah Indonesia tidak dapat menerima bahwa nine dash line itu masuk dalam ZEE dan Landas Kontinen Indonesia. Pemerintah China sering mengatakan mereka tidak mempunyai masalah dengan Indonesia di laut territorial. Apa yang dikatakan Pemerintah China, bahwa Indonesia tidak mempunyai sengketa kedaulatan atau sovereignty di laut territorial hal ini dapat dibenarkan karena Sembilan garis putus tidak menjorok hingga laut territorial Indonsia. Akan tetapi penarikan Sembilan garis putus yang ditarik dari Pulau Nasha berupa pulau, karang,law tide, elevation masuk ke wilayah ZEE Indonesia sehingga bertumpang tindih dengan ZEE dan Landas Kontinen Indonesia.

Kedaulatan teritorial adalah kedaulatan yang dimiliki oleh suatu Negara dalam melaksanakan yurisdiksi eksklusif di wilayahnya. ${ }^{16}$ Apabila kedaulatan ini dikaitkan dengan kondisi geografis Indonesia meliputi daratan, perairan pedalaman (internal waters), perairan kepulauan (archipelagic waters) dan laut territorial (territorial sea). ${ }^{17}$ Laut territorial adalah bagian terluar dari kedaulatan suatu Negara seluas 12 mil laut (Pasal 46 UNCLOS 1982 ), dalam hal pelaksanaan kedaulatan, suatu Negara tidak perlu meminta izin terhadap Negara lain untuk menjalankan kekuasaannya di wilayah teritorial, dalam Hukum Laut Internasional

14 https//news.detik.com/berita/d4859575. Diakses 15 Januari 2020

15 Prakasa, S. U. W; Purwo, Al. (2019), "Analisis Historical Traditional Fishing Right Pada Zona Ekonomi Eksklusif Indonesia", Legality, 27 (1): 83-97, h. 83

16 Adololf, H. (1991). Aspek-Aspek Negara dalam Hukum Internasional, Jakarta: Rajawali, h. 111

17 Kusumaatmaja, M. (2003), Hukum Laut Internasional, Bandung: Alumni, h. 67. 
dibedakan antara sovereignty dan sovereign rights. Sovereignty merujuk pada konsep kedaulatan yaitu laut teritorial (teritorial sea). Sovereign rights memberikan negara pantai untuk mengeksploitasi dan mengelola sumber daya alam di wilayah laut lepas tertentu seperti ZEE dan di bawah dasar laut yaitu Landasan Kontinen, dimana pelaksanaannya haruslah tunduk pada aturan hukum yang berlaku bagi masyarakat Internasional.

China tidak mengakui klaim Indonesia atas ZEE Natuna Utara karena zona itu berada di dalam Nine dash line yang diklaim China. Perairan sejenis ZEE dari Kepulauan Prata dan Paracel yang dipegang teguh oleh China yang disebut China sebagai Fishing grounds. Konsep penangkapan ikan tradisional yang dipakai China berbeda yang diatur dalam UNCLOS yaitu traditional fishing rights.

\section{Tindakan Pengamanan Dan Penegakan Hukum}

Dalam rangka mempertahankan kedaulatan Negara dan hak berdaulat Indonesia, maka tindakan tegas pernah dilakukan Indonesia terhadap kapal-kapal asing pelaku illegal fishing di perairan Indonesia. Tindakan penenggelaman kapal-kapal pelaku illegal fishing dilandasi Pasal 69 ayat (4) Undang Undang Nomor 45 Tahun 2009 tentang Perubahan Undang Undang Nomor 31 Tahun 2004 tentang Perikanan yang berbunyi : "Dalam hal melaksanakan fungsi pengawasan penyidik dan pegawai pemerintah dapat melakukan tindakan khusus berupa pembakaran dan atau penenggelaman kapal perikanan berbendera asing berdasarkan bukti permulaan yang cukup". Praktik pembakaran dan penenggelaman kapal ikan yang tertangkap tangan mencuri ikan adalah praktik yang biasa dilakukan banyak Negara lain. Di dalam Pasal 73 UNCLOS 1982 tidak mengatur secara eksplisit mengenai tindakan yang dapat dilakukan terhadap pelaku illegal fishing. ${ }^{18}$

Penelusuran sejumlah kejadian di Laut China Selatan menunjukan Coast Guard China dan kapal-kapal nelayan China memasuki wilayah ZEE Indonesia di Natuna Utara bukan kedaulatan Negara Indonesia di laut teritorial 12 mil. Apabila pihak China atau kapal berbendera negara lain masuk sampai wilayah 12 mil laut teritorial berarti telah melanggar kedaulatan Negara dan prinsip-prinsip hukum internasional. ZEE sendiri tidak berada di laut teritorial Indonesia, malainkan berada di laut lepas (high seas).

Di laut lepas tidak dikenal konsep kedaulatan Negara dan karenanya Negara tidak boleh melakukan tindakan penegakan hukum. Sebagai Negara, Indonesia harus menahan diri tidak terpancing dengan provokasi yang sering dilakukan oleh Coast Cuard di Laut China Selatan. Oleh karena itu kita tidak boleh mempersepsikan Coast Guard China melakukan pelanggaran teritorial atau kita sementara menghadapi pelanggaran teritorial atau pelanggaran kedaulatan yang harus dilakukan tindakan penegakan hukum. ${ }^{19}$

Menurut Prof. Hikmahanto apa yang terjadi di Natuna bukanlah situasi akan "perang" karena pelanggaran kedaulatan Negara. Kesembilan Garis putus ini tidak jelas koordinatnya. Peristiwa yang terjadi pada tahun 2020 Pemerintah China tidak pernah memberikan keterangan resmi apa yang diklaim selama ini tentang Nine dash line. Klaim Sembilan garis putus ini bertumpang tindih dengan ZEE Indonesia. Inipun yang tersurat dalam pernyataan resmi pemerintah China menghadapi insiden di Natuna. Dalam pernyataan tersebut dikatakan bahwa "Nelayan China tidak seharusnya ditangkap oleh DKPP kerena mereka melakukan peangkapan ikan di wilayah Traditional fishing grounds China. Konsep Traditional fishing Grounds tidak dikenal dalam UNCLOS 1982 dimana China dan

18 Juana, H, “Ceramah pada Seminar Indonesian Society of International Law Lecturers", Samarinda Tanggal 3 Agustus 2019.

19 Juana, H, "Press Release", 30 Januari 2020 
Indonesia sama-sama telah menjadi pihak dalam UNCLOS 1982, dalam Pasal 51 bahwa 'Traditional fishing right harus didasarkan pada perjanjian bilateral. Hingga saat ini Indonesia hanya mempunyai perjanjian Bilateral dengan Malaysia dan Australia tentang "Traditional fishing right'. ${ }^{20}$

Pada tahun 2016 Indonesia meresmikan nama baru Laut Natuna Utara untuk perairan di sisi Utara Kabupaten Natuna yang sangat strategis dan potensial berbatasan dengan laut Cina Selatan. Ada dua hal yang bersangkutan dengan Penamaan ini yaitu : pertama, agar ada keseragaman berdasarkan penamaan yang telah lebih dulu digunakan untuk konsesi eksploitasi migas di perairan tersebut. Sumber daya mineral di Natuna yaitu antara lain 16 blok migas 5 diantaranya telah mencapai tahap eksploitasi. Kedua, dengan pemberian nama berarti ada okupasi yang efektif. Okupasi atau pendudukan merupakan perolehan/penegakan kedaulatan atas wilayah yang terra nulius yaitu wilayah yang bukan dan sebelumnya belum pernah diletakkan di bawah kedaulatan suatu Negara, ${ }^{21}$ dalam kasus Sipadan dan Ligitan, Mahkamah memutuskan bahwa mayoritas tindakan efektivitas dilakukan Inggris dan dilanjutkan oleh Malaysia yang telah berhasil membuktikan adanya tindakan efektivitas yang cukup untuk mendapatkan kepemilikan atau hak berdaulat atas kedua pulau tersebut. Adapun Indonesia tidak memiliki cukup bukti sejak jaman Belanda dan tidak dilakukan tindakan efektivitas sebagai Negara berdaulat atas Sipadan dan Ligitan. Di sisi lain keputusan Indonesia untuk memberikan penamaan baru pada Laut Natuna menjadi Laut Natuna Utara memberikan bukti secara politik bahwa Indonesia mempunyai hak berdaulat di Laut Natuna Utara.

Menurut Direktur Jendral Hukum dan Perjanjian Internasional Kementerian Luar Negeri Damos Agusman Damoli "Negara yang melakukan protes sedang menggunakan hak hukumnya untuk bersikap 'persistent objection' terhadap klaim Negara lain". Dengan menggunakan hak ini, maka Indonesia tidak akan terikat pada klaim Tiongkok di perairan Natuna. Hal ini dapat menghalangi klaim tersebut menjadi embrio dan terkonsilidasi menjadi norma. Apabila Indonesia tidak menggunakan hak protesnya karena pesimis tidak merubah realitas, maka klaim tersebut bisa terkonsolidasi dan menjadi norma yang mengikat Indonesia di kemudian hari.Dalam hukum internasional disebut 'acguiescence' atau pengakuan diam-diam. ${ }^{22}$

Putusan Anglo Norwegian fisheries case sebagai rujukan Negara-negara yang mengklaim wilayah laut tanpa ada protes, tanggapan dan berlangsung lama. Kasus ini bermula pada tahun 1935 Norwegia mengeluarkan Firman Raja yang menyatakan laut negara Norwegia selebar 3 mil laut diukur dari pulau-pulau kecil terluar dihadapan pantai Norwegia kearah luar. Klaim sepihak Norwegia ini diikuti oleh Negara-negara yang mempunyai pulau-pulau kecil dihadapan pantai mereka seperti Negara-negara Amerika Latin Argentina, Chili. Peru. Inggris keberatan dengan cara penarikan garis pangkal tersebut dan membawa kasus ini ke Mahkamah Internasional. Pada tahun 1951 Mahkamah Internasional memutuskan bahwa "Firma Raja yang dikeluarkan Norwegia tidak pernah ada keberatan dan protes dari Negara-negara, ${ }^{23}$ dalam praktek hukum internasional tersebut menimbulkan acguiescence atau pengakuan diam-diam", dalam konflik Indonesia dan Tiongkok di Laut Natuna Utara, pemerintah Indonesia telah mengajukan nota protes pelanggaran ZEE Indonesia yang dilayangkan Kementerian Luar Negeri Indonesia setelah kapal penjaga pantai Tiongkok mengawal nelayan untuk mencuri ikan di Indonesia. Selain

20 Mauna, B. (2000), Hukum Internasional: Pengertian, Peranan dan Fungsi dalam Era Dinamika Global, Bandung: Alumni, h.

21 Sefriani. Op. Cit, h. 175.

22 https;www.medcom.id/ nota protes RI 7 Januari 2020

23 Kusumaatmadja, M. Op. Cit. h. 37 
melayangkan protes, Kemenlu juga memanggil Duta besar Tiongkok untuk menyampaikan protes keras. Menurut juru bicara Kemenlu Tiongkok, Geng Shuang menjawab nota protes Indonesia mengatakan negaranya tidak melanggar hukum internasional berdasarkan UNCLOS 1982.

Terdapat 4 poin sikap Indonesia soal klaim China di Laut Natuna yang disampaikan oleh Menteri Luar Negeri Indonesia (Press Release Menteri Luar Negeri Indonesia, Detik.com, tanggal 5 Januari 2020) Pertama, telah terjadi pelanggaran oleh kapal-kapal Tiongkok di wilayah ZEE Indonesia. Kedua,Wilayah ZEE Indonesia telah ditetapkan oleh hukum internasinal yaitu melalui UNCLOS 1982. Ketiga, Tiongkok merupakan salah satu part (anggota dari UNCLOS). Oleh karena itu merupakan kewajiban bagi Tiongkok untuk menghormati implementasi dari UNCLOS 1982. Keempat, Indonesia tidak pernah akan mengakaui Nine-dash line, klaim sepihak yang dilakukan Tiongkok yang tidak memiliki alasan hukum yang diakui oleh hukum Internasional terutama UNCLOS $1982 .{ }^{24}$

Sementara ini, Badan Keamanan Laut (Bakamla) bersama TNI AL Republik Indonesia dan Cost Guard China sama-sama bertahan di Natuna Utara dan tidak saling menyerang. Menurut pakar Hukum Internasional Hikmahanto bahwa "Negara yang menyerang pertama kali adalah melanggar hukum internasional". ${ }^{25}$ maka :

Dalam ketentuan UNCLOS Pasal 62 untuk pemanfaatan sumber kekayaan hayati

a) Negara pantai harus menggalakan tujuan pemanfaatan yang optimal sumber kekayaan hayati di ZEE

b) Negara pantai harus menetapkan kemampuannya untuk memanfaatkan sumber kekayaan hayati ZEE. Dalam hal Negara pantai tidak memiliki kemampuan untuk memanfaatkan seluruh jumlah tangkapan yang dibolehkan, maka negara pantai melalui perjanjian atau pengaturan lainnya dan sesuai dengan ketentuan, persyaratan dan peraturan perundang-undangan tersebut pada ayat 4, memberi kesempatan pada Negara lain untuk memanfaatkan jumlah tangkapan yang dapat diperbolehkan yang masih tersisa dengan memperhatikan secara hukum ketentuan Pasal 69 dan 70, khususnya yang bertalian dengan Negara berkembang yang disebut di dalamnya.

c) Dalam memberikan kesempatan memanfaatkan kepada Negara lain memasuki ZEE, Negara pantai harus memperhitungkan semua faktor yang relevan, termasuk inter alia pentingnya sumber kekayaan hayati di daerah itu bagi perekonomian Negara pantai yang bersangkutan dan kepentingan nasionalnya. Penangkapan ikan di ZEE harus dengan ijin Negara pantai. Penetapan jenis ikan yang boleh ditangkap, pengaturan musim dan daerah tangkapan, jumlah hasil tangkapan. Penurunan seluruh dan sebagaian hasil tangkapan oleh kapal tersebut di pelabuhan Negara pantai.

Apabila ekploitasi sumber daya alam hayati dimungkinkan melalui Undang-undang Penanaman Modal Asing atau Penanaman Modal Dalam Negeri maka ketentuan dan persyaratan bertalian dengan usaha patungan atau pengaturan kerjasama lainnya seperti persyaratan untuk latihan personil dan pengalihan teknologi perikanan, termasuk peningkatan kemampuan harus diutamakan. Indonesia sebagai Negara pantai harus menggalakkan tujuan pemanfaatan yang optimal sumber kekayaan hayati di ZEE tanpa mengurangi arti ketentuan Pasal 61.

Dalam hal Negara pantai tidak memiliki kemampuan untuk memanfaatkan seluruh jumlah tangkapan yang dibolehkan, maka Negara pantai tersebut melalui perjanjian atau

24 Pernyataan pers Menteri Luar Negeri Indonesia, tvOne, 26 Januari 2020

25 Juwana, H. Dialog tvOne, "Kapal China Masuk Laut Natuna”, 5 Januari 2020 
pengaturan lainnya dan sesuai dengan persyaratan dan peraturan perundang-undangan tersebut pada ayat 4, Negara pantai harus memperhitungkan semua faktor yang relevan, termasuk inter alia pentinggnya sumber kakayaan hayati tersebat bagi perekonomian dan kepentingan nasional untuk memanfaatkan surplus tersebut.

\section{P E N U T U P}

Berdasarkan uraian yang disebutkan di atas, dapat disimpulkan bahwa konflik di Laut China Selatan muncul karena klaim sepihak China atas laut China Selatan dengan mempergunakan konsep Nine dash line dan Traditional fishing ground yang tidak mempunyai landasan hukum dalam UNCLOS 1982. Indonesia, Flipina dan negara-negara di Kawasan Laut China Selatan bersikap tegas tidak mengakui konsep tersebut. Indonesia mempunyai sovereignty (kedaulatan) atas laut territorial, sovereign rights (hak berdaulat) di ZEE dan Landas Kontinen. Perairan Natuna Utara merupakan ZEE dan Landas Kontinen Indonesia. Okupasi yang efektif dilakukan oleh Indonesia melalui penamaan yang baru bagi Natuna menjadi Natuna Utara dan sama dengan konsesi migas yang telah dikeluarkan Indonesia untuk ijin-ijin perusahan eksploitasi Landas Kontinen, tanpa okupasi yang efektif sangat berbahaya karena akan menimbulkan acguiescence atau pengakuan diam-diam" karena Indonesia tidak pernah menyampaikan keberatan dan protes.

\section{DAFTAR PUSTAKA}

\section{Jurnal}

[1] Gumilang, E., Utomo, H., \& Buntoro, K. (2018). Dampak Aktivitas Militer Asing Di Zona Ekonomi Eksklusif Indonesia Terhadap Keamanan Maritim Indonesia. Jurnal Keamanan Maritim, 4(3): 21-42.

[2] Haiton, B. (2009). The Modern Origins of Chinas South China Sea Claims: Maps, Misunderstandings, and the Maritime Goebody. Sage Journals.

[3] Monteiro, S. (2020). Yurisdiksi Negara Pantai di Wilayah Delimitasi Maritim Zona Ekonomi Eksklusif yang Belum Ditetapkan Berdasarkan Ketentuan Hukum Laut Internasional (Study Di Timor Leste-Indonesia). Jurnal Komunikasi Hukum, 6 (1): 303-334.

[4] Prakasa, S. U. W., \& Purwo, Al. (2019). Analisis Historical Traditional Fishing Right Pada Zona Ekonomi Eksklusif Indonesia. Legality, 27 (1): 83-97.

[5] Rehatta, V. J. B. (2014). Penyelesaian Sengketa Perikanan di Laut Lepas Menurut Hukum Internasional. SASI, 20 (1): 62-68.

[6] Santoso, T. I. (2020). Aksi Agresivitas Cina Pada Zona Ekonomi Eksklusif Indonesia Laut Natuna Utara: Perspektif Tugas Pokok TNI”. Jurnal Kajian Lemhannas RI, Edisi 41 (Maret): 35-46.

[7] Tampi, B. (2017). Konflik Kepulauan Natuna Antara Indonesia dengan China (Suatu Kajian Yuridis). Jurnal Hukum Unsrat, 23 (10): 1-16.

\section{Buku}

[8] Adololf, H. (1991). Aspek-Aspek Negara dalam Hukum Internasional, Jakarta: Rajawali.

[9] Koers, A. W, (1994). Konvensi Perserikatan Bangsas-Bangsa tentang Hukum Laut, Yokyakarta: Gajah Mada University Press.

[10] Kusumaatmaja, M. (2003), Hukum Laut Internasional, Bandung: Alumni. 
[11] Mauna, B. (2000), Hukum Internasional: Pengertian, Peranan dan Fungsi dalam Era Dinamika Global, Bandung: Alumni.

[12] Subagyo, P. J. (2005). Hukum Laut Indonesia, Jakarta: Rineka Cipta.

[13] Sefriani, (2017). Hukum Internasional: Suatu Pengantar, Jakarta: Rajawali Pers.

\section{Online/World Wide Web dan Lain-Lain}

[14] https//news.detik.com/berita/d4859575. Diakses 15 Januari 2020.

[15] https;www.medcom.id/ nota protes RI 7 Januari 2020.

[16] Juana, Hikmahanto, Ceramah pada Seminar Indonesian Society of International Law Lecturers, Samarinda Tanggal 3 Agustus 2019

[17] Juwana, H. "Dialog tvOne: Kapal Cina Masuk Laut Natuna", Tanggal 5 Januari 2020

[18] Juwana, H, "Press Release", 28 Januari 2020

[19] Juana, H, "Press Release", 30 Januari 2020

[20] Pernyataan pers Menteri Luar Negeri Indonesia, tvOne,26 Januari 2020. 